\title{
TINDAK PIDANA MALPRAKTEK PROFESI MEDIS
}

\author{
${ }^{1}$ Jemmy Saifandi, ${ }^{2}$ Sumiadi, ${ }^{3}$ Muhammad Hatta \\ Email : sumiadi@unimal.ac.id \\ ${ }^{1}$ Mahasiswa Fakultas Hukum Universitas Malikussaleh \\ ${ }^{2}$ Dosen Fakultas Hukum Universitas Malikussaleh
}

\begin{abstract}
The medical profession malpractice crime in public life is currently an act of the Medical profession which is contrary to standard operating procedures (SOP), the law, and the applicable code of ethics.The government has made efforts to resolve criminal cases of malpractice in the medical profession, The country is responsible for regulating and protecting the right to optimal public health which is manifested by the creation of laws and regulations related to malpractice in the medical profession, with legal responsibility for the malpractice of the medical profession.However, although there have been several laws and regulations related to the malpractice of the medical profession, the number of malpractices in the medical profession continues to occur.

This research uses the juridical normative method which is a literature law research conducted by examining library materials or secondary data. This research is descriptive. The form of this research is that analysis is carried out in order to provide an overview or formulate problems according to existing circumstances or facts.

Based on the results of research and discussion, it can be concluded that regulations related to medical profession malpractice have been regulated in the Criminal Code (KUHP).Law Number 29 of 2004 concerning Medical Practice. Law Number 36 Year 2009 Concerning Health. Law Number. 36 of 2014 concerning Health Workers.Liability for malpractice in the medical profession must be proven by an error.In Law Number 29 of 2004 concerning Medical Practice, it is regulated if the medical profession is proven to have committed negligence or mistakes of the medical profession. Then the legal liability for medical profession malpractice is divided into three, namely, administrative responsibility, civil liability, and criminal responsibility.

The suggestion in this research is that regarding malpractice in the medical profession, it is hoped that the government will further sharpen and exacerbate criminal sanctions, especially imprisonment / agency and fines and administrative penalties for perpetrators of medical malpractice in order to cause a deterrent effect.
\end{abstract}

Keywords: Crime, Malpractice, Medical Profession 


\section{PENDAHULUAN}

Adanya hukum kesehatan berdampak besar terhadap pembangunan khususnya di bidang kesehatan. Hukum kesehatan termasuk dalam lex specialis yang secara khusus melindungi tugas profesi kesehatan (provider) dalam program pelayanan kesehatan manusia menuju ke arah deklarasi Health for All dan perlindungan khusus terhadap pasien (receiver) untuk mendapatkan pelayanan kesehatan. Istilah Malpraktek profesi medis yang dimaksudkan dalam skripsi ini adalah tindak pidana malpraktek profesi medis dalam kehidupan masyarakat saat ini yaitu tindakan profesi medis yang bertentangan dengan standar operasional prosedur (SOP), Undang-Undang, dan kode etik yang berlaku, baik disengaja maupun kelalaian yang mengakibatkan kondisi pasien semakin memburuk, atau bahkan menyebabkan kematian.

Kesalahan atau kelalaian dalam melakukan tindakan profesi medis akan menjadi pertanggungjawaban hukum (tergantung dari sifat kerugian yang ditimbulkan). Ada 3 (tiga) poin yang terkait dan tidak terpisahkan. Yang pertama adalah perbuatan yang tidak sesuai dengan norma, kedua karena kesalahan, atau karena kelalaian, dan ketiga mengandung akibat kerugian dalam ketentuan hukum. Kerugian hukum adalah kerugian yang diatur oleh hukum, yang dapat dipulihkan dengan membebankan tanggung jawab hukum kepada pelaku dan pelaku yang terlibat melalui jalur hukum.

Suatu aturan hukum dikatakan efektif setelah adanya sistem hukum penegakan hukumnya kemudian apakah peraturan itu ditaati dan mengikat bagi profesi medis dan masyarakat.Hukum pidana menduduki peranan penting karena hukum pidana mempunyai kedudukan yang istimewa, dalam arti hukum pidanatidak hanya terdapat dalam Undang-Undang hukum pidana saja namun juga terdapat di dalam berbagai Peraturan Perundang-Undangan lain di luar Kitab Undang-Undang Hukum Pidana (KUHP) seperti Undang-Undang tentang Kesehatan, Undang-Undang tentangTenaga Kesehatan, Undang-Undang tentang praktik kedokterandan sebagainya.

Malpraktek profesi medis yang dilakukan dalam melaksanakan profesi medis, merupakan suatu hal yang perlu untuk dikaji, karena kesalahan atau kealpaan tersebut mempunyai akibat yang sangat merugikan pasien baik secara fisik maupun batin. Apakah dengan pertanggungjawaban hukum pidana terhadap malpraktek profesi medis tersebut dapat menciptakan kondisi yang lebih baik.mengingat adanya pembangunan di segala bidang kehidupan dalam rangka mensejahterakan masyarakat.Pertanggungjawaban Hukum pidana terhadap malpraktek profesi medis digunakan sebagai sarana oleh pemerintah untuk meningkatkan rasa tanggungawab Negara/ Pemerintah dalam rangka mengelola kehidupan masyarakat modern yang semakin kompleks.

Berdasarkan uraian di atas penulis tertarik untuk melakukan analisis yang dituangkan dalam skripsi yang berjudul tindak pidana malpraktek profesi medis.

\section{METODE PENELITIAN}

Jenis penelitian ini adalah yuridis normatif. Prosedur penelitian yang menghasilkan data deskriptif yang berupa kata-kata tertulis atau tulisan dari orang-orang 
dan perilaku yang diamati dan berupaya untuk mencari makna. Pendekatan yang digunakan peneliti adalah Pendekatan Perundang-Undangan yang dilakukan dengan menelaah semua undang-undang dan regulasi yang berhubungan dengan objek penelitian. Berdasarkan sifatnya, penelitian bersifat deskriptif. Bentuk penelitian ini adalah analisis dilakukan guna memberikan gambaran atau merumuskan masalah sesuai keadaan atau fakta yang ada. dan memberikan gambaran tentang Tindak Pidana Malpraktek Profesi Medis berdasarkan Perundang- Undangan yang berlaku.

\section{PEMBAHASAN}

\section{Pengaturan Tindak Pidana Malpraktek Profesi Medis}

Suatu perbuatan merupakan perbuatan pidana apabila unsur-unsur yang ditentukan dalam Perundang-Undangan telah terpenuhi. Dalam hukum pidana maka kesalahan dapat disebabkan karena kesengajaan atau karena kelalaian (culpa).Malpraktek profesi medis dapat dipahami sebagai Perbuatan yang bertentangan dengan standar operasi prosedur (SOP) dan hukum yang berlaku, terlepas dari apakah perilaku tersebut disengaja atau lalai, akan menyebabkan kondisi pasien memburuk.

1. Ketentuan pidana Menurut KUHP

Tindak pidana malpraktek yang dilakukan oleh profesi medisyang menimbulkan luka atau matinya pasien merupakan suatu perbuatan tindak pidana bila memenuhi unsur kealpaan atas perbuatan yang menyebabkan orang lain luka sedemikian rupa atau mati, dalam pasal 359, 360 dan 361 merumuskan yaitu:

Di dalam KUHP, perbuatan yang menyebabkan orang lain luka sedemikian rupa atau mati dirumuskan didalam Pasal 359 dan 360. Adapun unsur-unsur dari pasal sebagai berikut:

1) Adanya unsur kelalaian (culpa)

2) Adanya wujud perbuatan tertentu

3) Adanya akibat luka berat atau matinya orang lain

4) Adanya hubungan kausal antara wujud perbuatan dengan akibat kematian orang lain itu,

Pasal 361 KUHP adalah pasal pemberatan pidana bagi pelaku dalam menjalankan suatu jabatan atau pencaharian yang melakukan tindak pidana yang disebut dalam Pasal 359 dan Pasal 360 KUHP. Berdasarkan pasal tersebut, profesi medis yang telah menimbulkan luka sedemikian rupa atau kematian yang berkaitan dengan tugas atau jabatan atau pekerjaannya, maka Pasal 361 KUHP memberikan ancaman pidana lebih berat.

2. Ketentuan pidana Menurut UU No 29 Tahun 2004 Tentang Praktik Kedokteran

ketentuan pidana terhadap profesi medis juga diatur pada Undang Undang No 29 Tahun 2004 Tentang Praktik Kedokteran terdapat dalam pasal-pasal sebagai berikut. Aturan mengenai ketentuan pidana yang relevan mengenai malpraktek profesi medis terdapat dalam pasal-pasal sebagai berikut:

UU nomor 29 tahun 2004 tentang praktek kedokteran memuat 5 Pasal yang mengatur mengenai ketentuan pidana yaitu Pasal 75 sampai dengan Pasal 80 termasuk pelanggaran hukum administrasi kedokteran yang diberi ancaman pidana.Tindak pidana 
yang bersumber dari pelanggaran kewajiban hukum administrasi. Tidak memiliki STR dari sudut hukum administrasi samadengan tidak memiliki wewenang untuk melakukan praktekprofesi medis. Perbuatan demikian diancam dengan ketentuan pidana. Bila praktek profesi medistanpa STR dan menimbulkan penderitaan bagi pasien maka itu telah menjadiperbuatan tindak pidana malpraktek profesi medis.

dilihat Dari subjek, ada tindak pidana memiliki subjek khusus / subjek tertentu, dan setiap orang memiliki subjek tertentu tercantum dalam Pasal 75, Pasal 76, dan Pasal 80 mengatur tentang tindak pidana yang hanya dapat dilakukan oleh subjek tertentu / khusus, yaitu tindak pidana hanya dapat dilakukan oleh dokter atau dokter gigi. Pasal 77, Pasal 78, dan Pasal 80 mengatur tentang tindak pidana yang dapat dilakukan siapa saja. "Setiap Orang" berarti individu dan korporasi. Sejauh menyangkut cara melakukan sesuatu, tindak pidana dalam "Undang-Undang Praktik Kedokteran" hanya mencakup tindak pidana formal yang dinyatakan sebagai suatu bentuk perilaku tanpa menyebutkan akibat dari perilaku tersebut.

Kesehatan ketentuan pidana Menurut UU No 36 Tahun 2009 Tentang Kesehatan

Kesehatan adalah hak bagi setiap orang, namun dalam hal menjaga kesehatan tentu seringkali didapati beberapa tindakan-tindakan yang mengancam kesehatan yang dapat berupa kesengajaan ataupun kelalaian.Hal-hal seperti ini diatur didalam UU No. 36 Tahun 2009 Tentang Kesehatan didalam Ketentuan Pidana pada Bab XX diatur didalam Pasal 190, 191, Pasal 193, dan Pasal 194 yaitu:

Ketentuan pidana terletak dalam Pasal 190, 191 192,193, dan 194. Aturan ini menegaskan agar pelaku dapat dikenakan dengan ketentuan pidana. Bila pasal-pasal dalam UU kesehatan tersebut dilanggar maka membuka jalan bagi timbulnya malpraktek profesi medis, baik secara perdata, pidana maupun administrasi. UndangUndang Nomor 36 tahun 2009 tentang Kesehatan memuat 5 Pasal yang mengatur mengenai ketentuan pidana yaitu Pasal 190 sampai dengan Pasal 194.

Dilihat dari subjeknya ada tindak pidana yang subjeknya khusus untuk subjek tertentu dan ada yang subjeknya setiap orang. Tindak pidana yang hanya dapat dilakukan oleh subjek tertentu/khusus diatur dalam 190 yaitu tindak pidana hanya dapat dilakukan khusus oleh Pimpinan fasilitas kesehatan dan/atau tenaga kesehatan yang melakukan praktek atau pekerjaan pada fasilitas pelayanan kesehatan.

Tindak pidana yang bisa dilakukan oleh setiap orang diatur dalam Pasal 191 sampai dengan Pasal 194. setiap orang adalah orang perseorangan dan korporasi. Tindak pidana dalam UU Kesehatan, ditinjau dari rumusannya dapat dibagi dua yaitu tindak pidana formil dan tindak pidana materiil. Tindak pidana formil dirumuskan sebagai wujud perbuatan yang tanpa menyebutkan akibat yang disebabkan oleh perbuatan itu. Tindak pidana materiil dirumuskan sebagai perbuatan yang menyebabkan suatu akibat tertentu, tanpa merumuskan wujud dari perbuatan itu.

\section{Ketentuan pidana Menurut UU No 36 Tahun 2014 Tenaga Kesehatan}

Aturan mengenai ketentuan pidana yang relevan mengenai malpraktek profesi medisjuga terdapat dalam UU No. 36 Tahun 2014 Tentang Tenaga Kesehatan diatur dalam Bab XIV yaitu : 
Dalam UU No 29 Tahun 2004 hanya memuat tentang administrasi menyangkut dengan izin praktik serta penggunaan gelar untuk meyakinkan pasien yang sebenarnya pelaku tidak pernah mendapatkan gelar tersebut dan juga dalam penggunaan alat, metode atau cara lain dalam memberikan pelayanan atau perawatan kepada masyarakat. Sedangkan jika menurut UU No 36 Tahun 2009 Tentang Kesehatan menitikberatkan kepada pimpinan atau korporasi dalam hal pelayanan kesehatan kepada masyarakat. Untuk aturan yang mengatur tentang kelalaian yang dimaksud dalam skripsi ini baru dimuat dalam UU No 36 Tahun 2014 Tenaga Kesehatan tetapi dalam UU ini hanya mengatur tentang kelalaian berat saja, tidak adanya pasal yang mengatur tentang kelalaian biasa dan juga tidak ada penjelasan bagaimana tindakan yang dikategorikan kedalam kelalaian berat dan kelalaian biasa.

Ancaman hukuman tentang kelalaian berat yang dimaksud dalam pasal 84 ayat 2 hanya 5 tahun, tergolong ringan karena menyangkut dengan nyawa pasien. Seharusnya dalam hal ini ancaman hukuman diberatkan dan harus setimpal dengan resiko perbuatannya, dalam uu tindak pidana lainnya yang memberatkan hukuman maksimal hanya 5 tahun itu hanya tindak pidana biasatidak sampai menghilangkan nyawa orang lain. Dengan ancaman hukuman tersebut dinilai tidak serius dalam menanggulangi terhadap malpraktek profesi medis, tidak seharusnya ancaman maksimal 5 tahun diperuntukkan untuk tindak pidana yang menghilangkan nyawa seseorang, dalam kuhp sendiri mengatur bahwa tindakan yang menghilangkan nyawa seseorang diancam maksimal 15 tahun penjara bahkan ada yang diancam maksimal 20 tahun penjara jika itu direncanakan. Ancaman hukuman sangat berpengaruh terhadap kehati-hatian profesi medis, agar menekan angka kelalaian malpraktek profesi medis jika dari ancaman maksimal hanya 5 tahun profesi medis menganggap itu sebagai hal yan biasa saja, namun jika ancamannya 15 tahun atau lebih profesi medis akan melihat itu sebagai hal yang serius sehingga meningkatkan kehati-hatian profesi medis dalam menjalankan profesinya.

kurangnya pemahaman mengenai batasan-batasan perbuatan malpraktek profesi medis secara terperinci maka menjadi penghambat penegakan hukum tersebut dalam melakukan upaya pertanggungjawaban pidana terhadap malpraktek profesi medis.

Ketentuan pidana dapat memberikan kepastian hukum bagi pasien dari rasa takut yang berlebihan apabila terjadi hal-hal yang menimbulkan akibat tertentu yang sangat merugikan. Perbuatan pidana atau tindak pidana adalah perilaku yang melanggar ketentuan pidana yang berlaku, Ketentuan Pidana merupakan upaya yang diancamkan kepada pelaku bila cara lain tidak dapat menemukan jalan keluar.

\section{Tindak pidana Malpraktek Profesi Medis}

Suatu perbuatan yang termasuk kategori malpraktek profesi medis atau tidak, Menurut Hubert W. Smith tindakan malpraktek profesi medis meliputi 4D, yaitu:

1. Adanya kewajiban (duty), dalam unsur ini tidak ada kelalaian jika tidak terdapat kewajiban, oleh karena itu unsur yang pertama ini menyatakan harus ada hubungan hukum antara pasien dengan para profesi medis. 
2. Adanya penyimpangan dalam pelaksanaan tugas (dereliction), yaitu profesi medis dalam melakukan kewajiban terhadap pasien melakukan tindakan penyimpangan dari standar profesi tersebut.

3. Penyimpangan akan mengakibatkan kerusakan (direct caution), dalam unsur ini terdapat hubungan kausal yang jelas antara tindakan medis yang dilakukan profesi medis dengan kerugian yang dialami pasien baik itu materil atau immateril.

4. Profesi medis akan menyebabkan kerusakan (damage), yaitu bahwa tindakan medis yang dilakukan profesi medis merupakan penyebab langsung timbulnya kerugian terhadap pasien. Yang termasuk kriteria tindakan medis yang bersifat malpraktek medis, yaitu:

a) Adanya pengaturan terhadap hukum.

b) Adanya hubungan hukum para pihak.

c) Adanya pelanggaran hak dan kewajiban.

d) Adanya akibat hukum yang ditimbulkan.

Malpraktek profesi medis ditinjau dari segi etika profesi dan segi hukum dapat dibedakan menjadi dua bentuk yaitu:

1. Malpraktek Etik

Yaitu profesi medis yang melanggar etika profesinya sebagai tenaga kesehatan, misalnya dokter yang melanggar etika profesi medis. Etika kedokteran yang dijabarkan dalam "Kode Etik Dokter" adalah seperangkat standar etika, prinsip, aturan, atau norma yang berlaku untuk semua dokter.

2. Malpraktek Yuridis

Soedjatmiko membedakan malpraktek yuridis ini menjadi tiga bentuk, yaitu malpraktek perdata (civil malpractice), malpraktek pidana (criminal malpractice) dan malpraktek administratif (administrative malpractice).

a. Malpraktek Perdata (Civil Malpractice)

Malpraktek perdata terjadi apabila terdapat hal-hal yang menyebabkan tidak terpenuhinya isi perjanjian (wanprestasi) didalam transaksi terapeutik oleh profesi medis atau terjadinya perbuatan melanggar hukum (onrechtmatige daad), sehingga menimbulkan kerugian kepada pasien. Dalam malpraktek perdata, ukuran malpraktek perdata yang disebabkan oleh kelalaian adalah kelalaian ringan (culpa levis). Karena jika terjadi kelalaian yang serius (culpa lata), maka perilaku tersebut termasuk dalam malpraktek pidana.Contoh pelanggaran perdata, seperti dokter yang melakukan operasi ternyata meninggalkan perban pada pasien.Setelah menemukan perban yang tersisa, lakukan operasi kedua untuk melepaskan perban yang tersisa. Dalam hal ini, kesalahan dokter bisa diperbaiki dan tidak akan berdampak negatif yang bertahan lama pada pasien.

\section{b. Malpraktek Pidana}

Malpraktek pidana terjadi apabila pasien meninggal dunia atau mengalami cacat akibat profesi medis kurang hati-hati atau kurang cermat dalam melakukan upaya perawatan terhadap pasien yang meninggal dunia atau cacat tersebut. Malpraktek pidana ada tiga bentuk yaitu: 
1) Malpraktek pidana karena kesengajaan (intensional), profesi medis tidak melakukan pertolongan pada kasus gawat padahal diketahui bahwa tidak ada orang lain yang bisa menolong, serta memberikan surat keterangan yang tidak benar. contoh: Melakukan aborsi tanpa tindakan medis.

2) Malpraktek pidana karena ketidakhati-hatian (recklessness), misalnya melakukan tindakan yang tidak lege artis atau tidak sesuai dengan standar profesi serta melakukan tindakan tanpa disertai persetujuan tindakan medis. contoh: Kurang hatihatinya profesi medis dalam memasang infus yang menyebabkan tangan pasien membengkak karena terinfeksi.

3) Malpraktek pidana karena kealpaan (negligence), misalnya terjadi cacat atau kematian pada pasien sebagai akibat tindakan profesi medis yang kurang hati-hati. contoh: Seorang bayi berumur 3 bulan yang jarinya terpotong pada saat profesi medisakan melepas bidai yang dipergunakan untuk memfiksasi infus.

c. Malpraktek Administratif

Malpraktek administratif terjadi apabila profesi medis melakukan pelanggaran terhadap hukum administrasi negara yang berlaku, misalnya menjalankan praktek bidan tanpa lisensi atau izin praktek, melakukan tindakan yang tidak sesuai dengan lisensi atau izinnya, menjalankan praktek dengan izin yang sudah kadaluarsa, dan menjalankan praktek tanpa membuat catatan medis.

Danny Wiradharma memandang malpraktek profesi medis dari sudut tanggungjawab profesi medis yang berada dalam suatu perikatan dengan pasien, yaitu para profesi medis tersebut telah melakukan praktek buruk. Dalam hal ini Amri Amir menyatakan malpraktek profesi medis adalah tindakan yang salah oleh dokter pada waktu menjalankan praktek, yang menyebabkan kerusakan atau kerugian bagi kesehatan dan kehidupan pasien, serta menggunakan keahliannya untuk kepentingan pribadi. Jadi, disimpulkan bahwa malpraktek medis adalah kelalaian atau ketidakhati-hatian seorang profesi medis dalam pelaksaan kewajiban profesionalnya, Ruang lingkup malpraktek profesi medis adalah kelalaian yang menyebabkan luka sedemikian rupa atau bahkan kematian. 


\section{KESIMPULAN}

Pengaturan tindak pidana malpraktek profesi medis dalamUndang-Undang No 29 Tahun 2004 hanya memuat 5 pasal yaitu pasal 75 sampai pasal 80 tentang administrasi menyangkut dengan izin praktek serta penggunaan gelar untuk meyakinkan pasien yang sebenarnya pelaku tidak pernah mendapatkan gelar tersebut dan juga dalam penggunaan alat, metode atau cara lain dalam memberikan pelayanana tau perawatan kepada masyarakat. Sedangkan jika menurut Undang-UndangNomor 36 tahun 2009 tentang Kesehatan memuat 5 pasal yaitu pasal 190 sampai dengan 194 yang menitik beratkan kepada pimpinan atau korporasi dalam hal pelayanan kesehatan kepada masyarakat. Untuk aturan yang mengatur tentang kelalaian yang dimaksud dalam skripsi ini baru di muat dalam Undang-Undang No 36 Tahun 2014 Tenaga Kesehatan tetapi dalam UU ini hanya mengatur tentang kelalaian berat saja, Ancaman hukuman tentang kelalaian berat yang dimaksud dalam pasal 84 ayat 2 hanya 5 tahun, tergolong ringan karena menyangkut dengan nyawas eseorang. Seharusnya dalam hal ini ancaman hukuman diberatkan dan harus setimpal dengan resiko perbuatannya, namun jika ancamannya 15 tahun atau lebih profesi medis akan meliha titu sebagai hal yang serius sehingga meningkatkan kehati-hatian profesi medis dalam menjalankan profesinya.

\section{Saran}

Terkait malpraktek profesi medis diharapkan yang akan datang pemerintah membuat suatu kebijakan khusus mengenai malpraktek profesimedis menyebutkan serta mencantumkan kualifikasi dan pertanggungjawaban pidana dalam hubungannya dengan malpraktek profesi medis, sehingga mempertajam juga memperberatsanksi pidana terutama pidana penjara/badan dan pidana denda serta pidana administrasi bagi pelaku tindak pidana malpraktek medis. 


\section{DAFTAR PUSTAKA}

Aloysius Wisnubroto, 1999,Kebijakan Hukum Pidana Dalam Penanggulangan PenyalahgunaanKomputer, Universitas Atmajaya, Yogyakarta.

Anthon F. Susanto, 2015, Penelitian Hukum Transformatif-Partisipatoris, Setara Press, Malang.

Bahder Johan Nasution, 2005,Hukum Kesehatan PertanggungJawaban Dokter, PT. Rineke Cipta, Jakarta.

Barda Nawawi Arief, 2008,KebijakanHukum Pidana Perkembangan Penyusunan KonsepKUHP Baru, Kencana Prenadamedia Group, Semarang.

Burhan Ashshofa, 2010, MetodePenelitian Hukum, RinekaCipta, Jakarta.

Danny Wiradharma, 1999, PenuntunKuliahKedokteranDan Hukum Kesehatan, EGC,Jakarta.

Departemen PendidikanDanKebudayaan, 1990,Kamus Besar Bahasa Indonesia, Depdikbud, Jakarta.

Hanafiah, M.Yusuf Dan Amri Amir, 1999,Etika Kedokteran Dan Hukum Kesehatan,Kedokteran EGC, Jakarta.

Hermin Hediati Koeswadji, 1998, Hubungan Kedokteran(Studi Tentang Hubungan Hukum Dalam Mana Dokter Sebagai SalahSatu Pihak), PT. Citra Aditya Bakti, Bandung.

J. Guwandi, 2004,Hukum Medik (Medical Law), Fakultas Hukum Universitas Indonesia, Jakarta.

Lilik Mulyadi, 2008,Bunga Rampai Hukum Pidana Perspektif Teoritis Dan Praktik,PT. Alumni, Bandung.

Matthew B. Mile Dan A. Michael Huberman, 1992, Analisis Data Kualitatif, Terjemahan Tjejep Rohendi Rohidi, Ul Press, Jakarta.

Mahmud Mulyadi, 2008, Criminal Policy, Pendekatan Integral Penal Policy Dan Non Penal Policy Dalam Penanggulangan Kejahatan Kekerasan, Pustaka Bangsa Press, Medan.

Nusye Ki Jayanti, 2009,Penyelesaian Hukum Dalam MalapraktikKedokteran, Pustaka Yustisia, Yogyakarta.

Oemar Seno Adji, 1991,Etika Profesional Dan Hukum Pertanggung Jawaban Pidana Dokter, Erlangga, Jakarta.

R. Abdoel Djamali \&Lenawati Tedjapermana, 1993, Tanggung Jawab Seorang Dosen Dalam Menangani Pasien, Abaradin, Jakarta.

Soejono Soekanto, 1986, Pengantar Penelitian Hukum, Cetakan L1l, U1 Press,Jakarta.

Sudarto, 1983,Hukum Pidana Dan Perkembangan Masyarakat, Sinar Baru, Bandung.

SofyanDahlan, 1999, Hukum Kesehatan Rambu- RambuBagiProfesiDokter, Badan PenerbitUndip, Semarang.

Fakultas Hukum Universitas Malikussaleh, 2016,Panduan Penulisan Tugas Akhir Skripsi.

Peter Mahmud Marzuki, 2009, Penelitian Hukum, KencanaPrenada Media Group, Jakarta.

Zainuddin Ali, 2010, MetodePenelitian Hukum, SinarGrafika, Jakarta.

Fakultas Hukum Universitas Malikussaleh, Pedoman Penulisan Tugas Akhir, Lhokseumawe, 2010. 
Tri Bawono Bambang, 2011, Kebijakan Hukum Pidana Dalam Penanggulangan Malpraktek Profesi Medis, Jurnal Hukum, Vol. XXV, No. 1.

Ngesti Lestari, 2001, "Masalah Malpraktek Etik Dalam Praktek Dokter", Kumpulan Makalah Seminar Tentang Etika Dan Hukum Kedokteran Diselenggarakan Oleh RSUD Dr. Sassiful Anwar, Malang.

Sartika Damopoli, 2017, “Tanggung Jawab Pidana Para Medis Terhadap Tindakan Malpraktek Menurut Undang-Undang Nomor 36 Tahun 2009 Tentang Kesehatan“, Lex Crimen, Vol . 6

World Medical Association, Statement On Medical Malpractice,2005, <Http://Www.Wma.Net/E n/30publications>, DiaksesPada Tanggal 04 April2019.

Widodo Tresno Novianto, 2015, Penafsiran Hukum Dalam Menentukan Unsur-Unsur Kelalaian Malpraktek Medik(Medical Malpractice), Yustisia,Vol. 4,No. 2. 